\title{
SUSTAINABLE REPORTING: PRACTICES AND CHALLENGES
}

\author{
Lyudmila MIHAYLOVA ${ }^{a^{*}}$, Emil PAPAZOV ${ }^{b}$ \\ aUniversity of Ruse ,,Angel Kanchev”, Bulgaria \\ ${ }^{b}$ University of National and World Economy - Sofia, Bulgaria
}

\begin{abstract}
Sustainable reporting is a modern topic. Nowadays, many organizations strive to achieve sustainable development in their activities, but a relatively small number of them have built systems for reporting and analysing the achieved sustainability. Therefore, reporting and assessment of sustainable development are understood primarily as part of the management process, providing information about the impact that the organization has on the economy, environment, and society. Their combination can help measuring the progress of an organization, setting goals, and outlining areas that will work for its gradual change. Enterprises improve their sustainable reporting through measurement, monitoring and control, showing a positive impact on the socio-economic development of the country and the region. This paper presents some main issues on the topic. The purpose is, on the base of case studies, to characterize and present the sustainable reporting as a challenging practice in Bulgaria.
\end{abstract}

KEYWORDS: business organizations, sustainable reporting, strategic assessment

DOI: 10.24818/IMC/2021/01.07

\section{INTRODUCTION}

The sustainable reporting of organizations provides information on their overall economic, environmental, managerial, and social performance. Studies show that environmental reports appeared first in the late 1980s in companies from the chemical industry with the purpose to build a good image. Step by step, other categories of enterprises (like small and medium-sized ones) began considering, in some way or another, the influence of the environment on their business activities. In this sense, sustainable reporting is becoming a trend that is gaining popularity in today's dynamic environment.

This paper aims to highlight important issues on practices and challenges of sustainable reporting, whereas the research objectives relate to analysing the practices for sustainable reporting in some Bulgarian industrial enterprises. A comparative analysis and a summary of the highlighted issues concerning the observed cases is also provided. The main hypothesis is that Bulgarian industrial enterprises have good practices in the sustainable reporting which are focused on their business specifics.

The analysis is based on the case study method. As criteria for the case study selection the following have been used: the enterprises belong to the Bulgarian manufacturing industry; for all companies, public data sources for sustainable reporting are available; all cases represent good examples comparable with good foreign practices. The framework of the data analysis is related to

\footnotetext{
* Corresponding author. E-mail address: 1mihaylova777@gmail.com
} 
enterprises with significant influence in their region, enterprises with potential for participation in mezzo-economic structures, etc.

The structure of the paper covers the importance of sustainable reporting for organizations and the examples of good practices in sustainable reporting from Bulgaria.

\section{IMPORTANCE OF SUSTAINABLE REPORTING FOR ORGANIZATIONS}

In recent times, more and more organizations prepare annual reports on their sustainable development, including a variety of indicators. There are many reasons why companies decide to prepare a report on sustainable development to stand out the idea of transparency in their activities, create a good image for the organization and its accountability. Another reason for the emphasis on sustainability reporting is usually the desire to improve management and business processes and activities. Such an action raises the awareness of stakeholders and creates an opportunity to attract potential investors, develop markets, and introduce new technologies, products, services. Enterprises strive to improve their sustainable reporting through measurement, monitoring and control, showing a positive impact on the socio-economic progress of the region and the country. Studies show that "the concepts of corporate voluntary reporting, corporate sustainability reporting and the economy in transition are similar and interlinked" (Masum, Latiff \& Osman, 2020).

Nowadays, Global Reporting Initiative is mainly concerned with the implementation of core standards for sustainable reporting worldwide (for details, see: https://www.globalreporting.org/about-gri/mission-history/). In practice, the Global Reporting Initiative offers a complete framework for sustainable reporting of all organizations. The sustainable reporting also reflects the way in which the organization copes with the accepted requirements for such a development, as well as the impact, either positive or negative, on the economic, ecological, or social environment. An additional element of this reporting is the comparison on various factors with other organizations in a country and / or a region, as well as on introduced new technologies. The largest database of sustainable reports is maintained on the United Nations Global Compact website (United Nations Global Compact, 2021). It could be noted that by incorporating the Principles of the United Nations Global Compact into strategies, policies, and procedures, and establishing a culture of integrity, companies are not only upholding their basic responsibilities to people and environment, but also setting perspectives for a long-term success (for details, see: https://www.unglobalcompact.org/what-is-gc/mission/principles). It is comment by many authors in different business activities (Pakš̌ová, 2017; Rahman \& Yadlapalli, 2015; Suttipun, 2015; Niculescu, et al., 2020).

The international organization "Global Reporting Initiative" has been active since 1997 and, based on ongoing consultation and cooperation with many organizations and experts, has continuously improved the reporting of sustainable development. The main goal is to create international reporting standards, voluntarily used in reporting economic, environmental, and social activities. The first variant of the Global Reporting Initiative was published in 2000, known as the G1 Modifications followed in 2002 (GRI - G2), 2006 (GRI - G3), 2013 (GRI - G4) and the development of a consolidated package of standards in 2016 - GRI standards - global standards for sustainability reporting - the GRI Standards). The Standards hold on to be updated and added to, including new standards on topics like tax (2019) and waste (2020). (For details, see: https://www.globalreporting.org/about-gri/mission-history/).

The latest additions are related to the UN's understanding that taxes play a very important role in achieving the sustainable development goals and are a key mechanism through which organizations contribute to the economies of countries. Clear and detailed tax reporting shows the impact on sustainability, strategy, and performance. The business activities of enterprises and tax payments for each country are made public (for details, see: https://www.globalreporting.org/standards/standardsdevelopment/topic-standard-project-for-tax/). The application of the first global standard for 
reporting tax transparency enables organizations to make public information about their tax practices. Investors, labour organizations and other stakeholders fully support this standard, because it ensures tax transparency.

Regarding the Waste Standard published in May 2020, the aim is to show more clearly the relationship between the materials used and the waste received. The idea is to assist organizations identifying and managing their waste impacts throughout the value chain. The standard emphasizes the way in which organizations measure waste, given the environmental impact, impact on the society and the economy. Businesses are encouraged to reduce waste and seek opportunities for recycling business solutions based on the world's best waste management practices (for details, see: https://www.globalreporting.org/standards/standards-development/topic-standard-project-forwaste/).

Sustainability reporting allows organizations to present their impact on a large range of issues, including the risks and opportunities they face and to make smart strategic decisions. Today's investors increasingly need detailed information that goes beyond traditional financial reporting to link the strategy, governance, social and environmental performance of organizations with their competitive advantages and value creation. The complexity of the causal relationship between events creates risks and affects sustainability (Kirova, 2018; Stanković, Tomić \& Stanković, 2020; Arvidsson, 2019). The concept of sustainable development and reporting must be applied throughout the value chain (Lukic, Lalic \& Matovic, 2015). Some authors identify key indicators for the implementation of environmental, social, and corporate governance at the corporate level in support of investor decisions and are part of sustainable reporting (Kocmanová, Němeček \& Dočekalová, 2012).

Sustainable development is not only linked to financial reporting, but also focuses on additional reports and information on non-financial indicators, social impact reports, social responsibility, even integrated reports. Most often, they cover all aspects of the organization, including social, ethical, and environmental areas that are important to the stakeholders (Kwarcińska, 2020; Man \& Bogeanu-Popa, 2020; Gilina, 2015). Some authors underline "the need to integrate sustainable reporting practices into overall management reporting" (Băndoi et al., 2021; Denčić-Mihajlov \& Zeranski, 2017; Eccles \& Krzus, 2010; Radulescu, \& Nastase, 2012). There is an opinion that the implementation of green, sustainable, responsible investments has become a priority for each organization, and they relate to sustainable reporting (Chițimiea, et al., 2021).

In this regard, the following reasons can be outlined for organizations to carry out such a reporting:

- to provide an opportunity for stakeholders to understand the external impact of the organization and its progress in sustainable development;

- to meet their legal obligations, performance standards and voluntary initiatives;

- to improve their reputation and brand loyalty;

- to show the ways in which on the one hand the organization influences, and on the other - is influenced by the expectations in the field of sustainable development;

- to assist in the implementation of their long-term strategy, as well as in the development of specific business plans;

- to highlight the connection between financial and non-financial indicators;

- to highlight some ecological problems;

- to compare their progress with that of other organizations, as well as to balance the development of different departments in the organization.

In Bulgaria, there is good practice for sustainable reporting of enterprises in different fields. This reporting is linked to the companies' strategy and is disclosed to stakeholders.

The following section presents good practices (case studies) for sustainability reporting and its relationship to the enterprise goals and strategy. 


\section{GOOD PRACTICES IN SUSTAINABLE REPORTING FROM BULGARIA}

The Bulgarian experience in the field of sustainable reporting is diverse. The used methodology of research is based on method of case study analysis. The case study as a method of research relies on an individual case, not on a sample. We focus on a case and can make detailed observations over a specific issue. In the sustainable reporting practice case studies are also useful in the early stages of research, when the goal is to explore ideas, instruments and to prepare for a larger study. The case study method is applicable in the field of business analyses. Criteria for case study selection are the business activity of the enterprise (industrial enterprises), importance of the enterprise for the region of Bulgaria, public information sources, data sources - sustainable reporting documents, strategic documents, etc.

This paper describes two case studies. The first one is an example for a good practice in a Bulgarian enterprise, which is a part of the company Dormakaba. Dormakaba has been on the Bulgarian market for more than 20 years. It specializes in the production and installation of automatic sliding doors, soundproof partition walls, security and access control systems, door equipment (door accessories), systems for glass facades and glass fittings. The enterprise has its own facility in Sofia, Bulgaria, which houses offices, warehouses, production area and showroom.

It is important to note that the company Dormakaba identifies sustainability "as one of the key success factors to becoming recognized as a trusted industry leader. That is why sustainability has been anchored as a cornerstone of the company's corporate strategy." (For details, see: https://report.dormakaba.com/2019_20/strategy/). The company aspires to popularize "sustainable development along the value chain as part of its economic, environmental and social responsibility toward current and future generations" (for details, see: https://report.dormakaba.com/2019_20/strategy/). It engages in an open and clear dialogue with stakeholders to identify strategies and actions based on obvious goals and permanent improvements. Dormakaba adheres to the preventive principle as a basis for sustainability. Adverse effects on the environment and health must be ignored in advance as much as possible by all employees in all company's business activities. So, this is a modern understanding about strategic management, sustainability, and corporate social responsibility.

Having in mind the strategic approach, "Dormakaba has committed to achieving seven overarching sustainability targets in its corporate strategy" (see Table 1), (for details, see: https://report.dormakaba.com/2019_20/strategy/).

The company is about to achieve several of its sustainability goals, especially regarding its commitment to reduce carbon emissions and the operation of the supplier's sustainability audit system. For the last, the Dormakaba has identified processes which were not in compliance with the Supplier Code of Conduct, thus not allowing the company to participate in its supplier engagement program. (This is rolled out in the financial year 2020/21). Besides, the company has met the filing requirements of the Science Based Targets Initiative as planned. It had also expected to submit its long-term reduction targets for Scope 1, 2 and 3 carbon emissions by September 2020, but the impact of the Covid-19 pandemic has noted challenges in terms of baseline setting. This has been discussed with the management of the company do expect to have the reduction targets validated by them within the financial year 2020/21 (for details, see: https://report.dormakaba.com/2019_20/ strategy/).

The Dormakaba Company has shown marginal improvements of the additional targets, with a deadline at the end of the financial year 2020/21. So, the case study shows that the goal is to increase the share of production certified under ISO 14001 and to increase the share of revenue of products with declarations for environmental and / or health products. The management believes that with the implementation of the planned initiatives in the financial year 2020/21, it will achieve or be close to achieving the corporate goals. 
The case study shows that for the targets, with a deadline of the end of the financial year 2021/22, the management of Dormakaba continue to work. Given the current planning, the goal related to the energy management systems is a particular challenge.

The case study shows that sustainable reporting is an important issue of the nowadays management practice. It is based on the public company information.

The next case study presents sustainable reporting practice of another Bulgarian company, Orgachim JSC, located in the town of Ruse. Orgachim is an innovative, market-oriented company with history more than 120 years. It is one of the biggest and best equipped chemical enterprises in South-Eastern Europe, with a long history in the manufacturing of paints and coatings, with modern installations and significant resources. As a leading manufacturer, Orgachim provides a full satisfaction to its customers and partners, both with the quality, durability and efficiency of the products, as well as with the beauty of the colours (for details, see: https://www.orgachim.bg).

Table 1. Strategic targets of the Dormakaba Company

\begin{tabular}{|c|c|c|}
\hline Target & Deadline & Financial year 2019/20 \\
\hline $\begin{array}{l}\text { Meet target submission requirements as } \\
\text { part of the commitment to the Science } \\
\text { Based Targets initiative. }\end{array}$ & September 2020 & $\begin{array}{l}\text { Scope } 3 \text { carbon inventories } \\
\text { developed; } 92 \% \text { Scope } 1 \text { and } \\
\text { Scope } 2 \text { emissions reported. }\end{array}$ \\
\hline $\begin{array}{l}\text { Reduce Scope } 1 \text { and } 2 \text { carbon emissions } \\
\text { by } 5 \% \text { tCO2e (baseline 2017/18). }\end{array}$ & $\begin{array}{l}\text { End of financial } \\
\text { year } 2020 / 21\end{array}$ & $\begin{array}{l}-15 \% * \\
(* \text { Of which } 9 \text { pp. are attributable } \\
\text { to increased purchase of green } \\
\text { electricity and energy efficiency } \\
\text { projects, and the rest due to } \\
\text { various factors including the } \\
\text { business impact of Covid-19). }\end{array}$ \\
\hline $\begin{array}{l}\text { Increase the share of ISO } 14001 \\
\text { certified production sites to }>50 \% \\
\text { (baseline 2017/18). }\end{array}$ & $\begin{array}{l}\text { End of financial } \\
\text { year } 2020 / 21\end{array}$ & $36 \%$ \\
\hline $\begin{array}{l}\text { All manufacturing sites maintain health } \\
\& \text { safety management systems based on } \\
\text { ISO } 45001 \text { or OHSAS } 18001 .\end{array}$ & $\begin{array}{l}\text { End of financial } \\
\text { year 2021/22 }\end{array}$ & $73 \%$ \\
\hline $\begin{array}{l}\text { All manufacturing sites maintain energy } \\
\text { management systems based on ISO } \\
50001 \text {. }\end{array}$ & $\begin{array}{l}\text { End of financial } \\
\text { year 2021/22 }\end{array}$ & $21 \%$ \\
\hline $\begin{array}{l}\text { Increase the revenue share of products } \\
\text { with environmental and/or health } \\
\text { product declarations to }>30 \% \text {. }\end{array}$ & $\begin{array}{l}\text { End of financial } \\
\text { year } 2020 / 21\end{array}$ & $19 \%$ \\
\hline $\begin{array}{l}\text { Operationalize a supplier audit system } \\
\text { based on sustainability criteria. }\end{array}$ & $\begin{array}{l}\text { End of financial } \\
\text { year } 2020 / 21\end{array}$ & $\begin{array}{l}475 \text { suppliers invited for Eco } \\
\text { Vadis assessment; Procedures } \\
\text { for non-participation and non- } \\
\text { compliance approved. }\end{array}$ \\
\hline
\end{tabular}

Source: Company’s web: https://report.dormakaba.com/2019_20/strategy/, 10 March 2021

It is important to note that caring for nature is one of the main priorities of the company. Company's clients could find some of the products have been marked with the logo of Eurofins Laboratory. These guarantees quantities of Volatile Organic Compounds below $1 \mathrm{~g} / \mathrm{L}$, which is 30 times below the maximum permissible standards of the market. The mentioned paints protect health and environment. A stronger future protection in this direction will be one of the main targets of Orgachim in the future. The management of the company takes as its important task to educate society and consumers about environmentally friendly products and practices. In 2018, they also 
continue the preparation of the initiative with the National Association of Municipalities and with partner chain stores in order to educate people about the need to collect and store waste from chemical products. The company's team keeps focusing on the certification of the product quality and safety. Adding the TÜV logo on the packaging, as a guarantee for international high standards is also a part of sustainable ideas management. (For details, see: https://www.orgachim.bg/care-fornature/?lang=en).

Sustainability reporting of Orgachim provides information about their overall social and managerial performance. In 2017, Orgachim is implementing initiatives and projects that make the environment more colourful, welcoming and renovate. They donate over 12,900 kilograms of paints at a market value of nearly BGN 40000 (ca. 20000 Euro). Of these, 29.4\% were donated to social centres, $20.6 \%$ to foundations, $18.9 \%$ to kindergartens, $17.9 \%$ to schools, $8.8 \%$ to town halls and $4.4 \%$ to improve the urban environment (for details, see: https://rousse.info). The idea is to provide an opportunity for stakeholders to understand the impact of Orgachim and its progress in sustainable development.

In 2016, Orgachim JSC organized a partnership initiative with the Transformers' Association "Draw me a wall". The platform supports implementation of artistic solutions for public urban spaces and interiors of socially significant buildings throughout the country. So, 34 artists from all over the country applied for the opportunity to decorate 4 main buildings in Sofia, Plovdiv, Pazardzhik and Gabrovo. BGN 30,000, $576 \mathrm{~kg}$ of paint and 28 full working days of work by four artists have been invested in the initiative. The initiative generates over 100 publications in national media and thousands of shares and likes on social media. It is a part of the sustainable reporting initiatives of the company Orgachim. The idea is to improve the reputation and brand loyalty and to show the ways in which organization influences and is influenced by the expectations in the field of sustainable development.

The comparative analysis of the observed two cases can be summarized in the following table:

Table 2. Comparative analysis of the sustainable reporting practice: the cases of Dormakaba and Orgachim companies

\begin{tabular}{|l|l|}
\hline \multicolumn{1}{|c|}{ Dormakaba } & \multicolumn{1}{c|}{ Orgachim } \\
\hline On the Bulgarian market for more than 20 years & $\begin{array}{l}\text { An innovative, market-oriented company with } \\
\text { history more than 120 years }\end{array}$ \\
\hline $\begin{array}{l}\text { Specializes in the production and installation of } \\
\text { automatic sliding doors, soundproof partition } \\
\text { walls, security and access control systems, door } \\
\text { equipment }\end{array}$ & $\begin{array}{l}\text { Specializes in the manufacturing of paints and } \\
\text { coatings, with modern installations and } \\
\text { significant resources }\end{array}$ \\
\hline $\begin{array}{l}\text { Sustainability is one of the two bases of the } \\
\text { company's business strategy }\end{array}$ & $\begin{array}{l}\text { Sustainability reporting has to improve the } \\
\text { reputation and brand loyalty and to show the } \\
\text { ways in which organization influences and is } \\
\text { influenced by the expectations in the field of } \\
\text { sustainable development }\end{array}$ \\
\hline $\begin{array}{l}\text { The important managerial task is an open and } \\
\text { clear dialogue with stakeholders to identify } \\
\text { strategies and actions based on obvious goals } \\
\text { and permanent improvements }\end{array}$ & $\begin{array}{l}\text { The important managerial task is the } \\
\text { education of society and consumers about } \\
\text { environmentally friendly products and } \\
\text { practices }\end{array}$ \\
\hline $\begin{array}{l}\text { Sustainability goals, especially about its } \\
\text { commitment to reduce carbon emissions and the } \\
\text { operation of the supplier's sustainability audit } \\
\text { system }\end{array}$ & $\begin{array}{l}\text { Sustainability reporting provides information } \\
\text { about their overall social and managerial } \\
\text { performance }\end{array}$ \\
\hline
\end{tabular}

Source: Own case study research 
The analysis shows that the sustainable reporting of the two investigated industrial enterprises in Bulgaria is focused on their business specifics and business environment.

\section{CONCLUSIONS}

Many business organizations set the goal to achieve sustainability, but a relatively small number of them created systems for reporting and assessing the progress in this direction. This is because reporting and assessment of sustainable development are not fully accepted as a part of the strategic management process that provides feedback about the impact that the organization has on the economy, environment, and society. Their implementation can help measuring the progress of the organization, setting goals, and outlining areas that will work for its gradual change.

Enterprises can improve their sustainable reporting by monitoring and analysing measures that has a positive impact on the socio-economic development of the country and the region. The Bulgarian economy offers good examples on this topic that deserve to be analysed and promoted. This paper is a part of research on the topic of sustainable reporting in the industrial enterprises. It is an attempt to do an initial study on the topic and will be expanded in the future. Our vision on future research in this area is connected with search for trust in the sustainable reporting. This can be achieved by linking sustainable reporting to the internal control systems of organizations. Organizations should focus on integrating sustainable reporting into internal control activities and auditing. This will give confidence in the importance of sustainable reporting practice in the future and will provide an opportunity for stakeholders to understand the progress in sustainable development.

\section{ACKNOWLEDGMENT}

This research has been funded by the Scientific Research Project "2021-BM-01 Study of the business systems' adaptation to the conditions of a dynamically changing environment", funded by the Scientific Research Fund of the University of Ruse "Angel Kanchev", Bulgaria.

\section{REFERENCES}

Arvidsson, S. Ed. (2019). Challenges in Managing Sustainable Business Reporting, Taxation, Ethics and Governance. Palgrave Macmillan.

Băndoi, A., Bocean, C. G., Del Baldo, M., Mandache, L., Mănescu, L. G., Sitnikov, C. S. (2021). Including Sustainable Reporting Practices in Corporate Management Reports: Assessing the Impact of Transparency on Economic Performance. Sustainability, 13, 940. https://doi.org/10.3390/su 13020940

Denčić-Mihajlov, K., \& Zeranski, S. (2017). Development of Sustainability Indicators: Approaches, Challenges and Opportunities. Facta Universitatis, Series: Economics and Organization, 14(4), 291-306.

Chițimiea, A., Minciu, M., Manta, A. M., Ciocoiu, C. N., \& Veith, C. (2021). The Drivers of Green Investment: A Bibliometric and Systematic Review. Sustainability, 13(6), 1-25.

Dormakaba, Strategy, retrieved from: https://report.dormakaba.com/2019_20/strategy/, Accessed on: 10 March 2021.

Eccles, R. G., \& Krzus, M. P. (2010). Challenges in Managing Sustainable Business Reporting. Taxation, Ethics and Governance. John Wiley \& Sons, Inc., Hoboken, New Jersey.

Gilina, N. (2015). Guidelines for Institutional Changes in the Residential Real Estates Market. Ikonomiceski $i$ Sotsialni Alternativi, (2), 101-112.

GRI. Our mission and history, retrieved from: https://www.globalreporting.org/about-gri/mission-history/, Accessed on: 07 February 2021

GRI. Topic Standard Project for Tax, retrieved from: https://www.globalreporting.org/standards/standardsdevelopment/topic-standard-project-for-tax/, Accessed on: 07 February 2021 
GRI. Topic Standard Project for Waste, Retrieved from: https://www.globalreporting.org/standards/ standards-development/topic-standard-project-for-waste/, Accessed on: 07 February 2021

Kirova, M. (2018). A new approach to identify risks in innovations, based on their graphic time comparisons, Book Series: International Management Conference, Proceedings of the 12-th International Management Conference "The Role of Management in the Economic Paradigm of the XXI-st Century" November 1st-2nd, 2018, Bucharest, Romania, pp. 233-240.

Kocmanová, A., Němeček, P., \& Dočekalová, M. (2012). Environmental, social and governance (ESG) key performance indicators for sustainable reporting. In 7th International Scientific Conference Business and Management 2012. Vilnius Gediminas Technical University, Lithuania. https://doi.org/10.3846/bm.2012.085

Kwarcińska, A. (2020). Reporting problems of corporate social responsibility. Ekonomia i Prawo. Economics and Law, 19(3), 523-532. doi:10.12775/EiP.2020.035

Lukic, R., Lalic, S. M., \& Matovic, I. (2015). The role of sustainable reporting to performance management in the retail food. In Sixth International Scientific Agricultural Symposium "Agrosym 2015", Jahorina, Bosnia and Herzegovina, October 15-18, 2015. Book of Proceedings (pp. 1848-1854).

Man, M., Bogeanu-Popa M-M. (2020). Impact of Non-Financial Information on Sustainable Reporting of Organisations' Performance: Case Study on the Companies Listed on the Bucharest Stock Exchange. Sustainability, 12(6), 2179. https://doi.org/10.3390/su12062179

Masum, M. H., Latiff, A. R. A., \& Osman, M. N. H. (2020). Voluntary Reporting, Sustainable Reporting and Transition Economy. International Business and Accounting Research Journal, 4(2), 81-88. http://dx.doi.org/10.35474/ibarj.v4i2.138

Niculescu, M-A., Platagea Gombos, S., Lazar, V., \& Buzoianu, O. (2020). Sustainable Development from the Perspective of the Heritage Management of the Sarata Monteoru Tourist Resort. Proceedings of the International Management Conference, Faculty of Management, Academy of Economic Studies, Bucharest, Romania, vol. 14(1), pp 235-241.

Orgachim JSC. Sustainable Solutions with Care for Nature, retrieved from: https://www.orgachim.bg/carefor-nature/?lang=en, Accessed on: 20 March 2021

Orgachim JSC. Annual corporate social responsibility report, retrieved from: https://rousse.info, Accessed on: 28.02.2017

Pakš̌ová, R. (2017). Sustainability reporting in the Slovak republic. In Sustainability Reporting in Central and Eastern European Companies (pp. 143-155). Springer, Cham.

Radulescu, C. V., Nastase, M. (2012). Sustainable development projects-management and involvement in the European Union. Ekonomika Poljoprivrede, 59(3), 232.

Rahman, S., \& Yadlapalli, A. (2015). Sustainable practices in luxury apparel industry. In Handbook of sustainable luxury textiles and fashion (pp. 187-211). Springer, Singapore.

Suttipun, M. (2015). Sustainable development reporting: evidence from Thailand. Asian Social Science, $11(13), 316-326$.

Stanković, J., Tomić, Z., \& Stanković, J. (2020). Socio-economic Impact of Natural Disasters in the Republic of Serbia. Economic Analysis, 53(2), 20-38.

United Nations Global Compact. The Ten Principles of the UN Global Compact, retrieved from: https://www.unglobalcompact.org/what-is-gc/mission/principles, Accessed on: 07 March 2021. 